\title{
ANALYTICAL METHOD DEVELOPMENT AND VALIDATION FOR THE ESTIMATION OF IMATINIB MESYLATE AND ITS DIMER IMPURITY IN PHARMACEUTICAL FORMULATION BY REVERSE-PHASE HIGH-PERFORMANCE LIQUID CHROMATOGRAPHY
}

\author{
ARUN KUMAR KUNA*, GANAPATY SERU, GADELA VENKATA RADHA \\ Department of Pharmaceutical Analysis, Gitam Institute of Pharmacy, Gitam University, Gandhi Nagar, Rushikonda, \\ Visakhapatnam - 530 045, Andhra Pradesh, India. Email: kunaarun@yahoo.co.in
}

Received: 01 July 2017, Revised and Accepted: 30 November 2017

ABSTRACT

Objective: The present study is to develop a simple, specific, and validated reverse-phase high-performance liquid chromatography (HPLC) method for the determination of imatinib mesylate and its dimer impurity in pharmaceutical dosage form.

Methods: A HPLC instrument incorporated with column HiQ Sil C18 (250 mm $\times 4.6 \mathrm{~mm}, 5 \mu \mathrm{m})$, mobile phase as methanol and acetate buffer pH 3.5 in the ratio of $80: 20 \mathrm{v} / \mathrm{v}$ was used for the determination of the imatinib mesylate and its dimer impurity. The detection wavelength was set at $273 \mathrm{~nm}$. The flow rate of the mobile phase was $1.0 \mathrm{~mL} / \mathrm{min}$.

Results: The retention time for imatinib mesylate was 8.060, and for dimer impurity, it was 11.398 . The calibration plot was linear $\left(\mathrm{R}^{2}=0.9971\right)$ and the \% mean recoveries for imatinib mesylate were in the range of 99.83-101.57, and for dimer impurity, it was in the range of $98.16-99.18$. The limit of detection concentration was found to be $0.570 \mu \mathrm{g} / \mathrm{ml}$ for imatinib mesylate and $0.033 \mu \mathrm{g} / \mathrm{ml} \mathrm{dimer} \mathrm{impurity} \mathrm{and} \mathrm{limit} \mathrm{of} \mathrm{quantification}$ concentration was $1.728 \mu \mathrm{g} / \mathrm{ml}$ for imatinib mesylate and $0.099 \mu \mathrm{g} / \mathrm{ml}$ dimer impurity.

Conclusion: The projected method was validated and successfully functional for the estimation of imatinib mesylate and dimer impurity in formulations. It can be adopted apparently for routine quality control and research tests.

Keywords: Imatinib mesylate, Validation, Dimer, Reverse-phase high-performance liquid chromatography.

(C) 2018 The Authors. Published by Innovare Academic Sciences Pvt Ltd. This is an open access article under the CC BY license (http://creativecommons. org/licenses/by/4. 0/) DOI: http://dx.doi.org/10.22159/ajpcr.2018.v11i3.21073

\section{INTRODUCTION}

Imatinib is an antineoplastic drug used to treat leukemia, especially chronic myelogenous leukemia (CML). Imatinib is a tyrosine kinase inhibitor (TKI). A kinase is an enzyme that promotes cell growth. Imatinib mesylate is a small molecule that inhibits the c-Abl protein tyrosine kinase, a kinase specifically important for proliferation of CML. Imatinib was the first TKI to be approved by the US food and drug administration for the treatment of CML. The chemical structure of imatinib mesylate is shown in Fig. 1.

Imatinib mesylate 4-[(4-methyl-1-piperazinyl) methyl]-N-[4methyl-3-[[4-(3-pyridinyl)-2-pyrimidinyl]amino]phenyl]benzamid methanesulfonate and has a chemical formula $\mathrm{C}_{29} \mathrm{H}_{31} \mathrm{~N}_{7} \mathrm{O} \cdot \mathrm{CH}_{3} \mathrm{SO}_{3} \mathrm{H}$. Its molecular weight is $589.7 \mathrm{~g} / \mathrm{mol}$. It is white to creamish yellow crystalline powder and freely soluble in $0.1 \mathrm{~N} \mathrm{HCl}$, methanol, and sparingly soluble in dimethyl ether [1]. Dimer impurity is chemically known as 4,4-(piperazine-1,4-diylbis (methylene))bis(N-(4-methyl-3(4(pyridine-3-yl)pyrimidine-2-yl) amino)phenyl)benzamide. Because analytical methods must be validated before use in pharmaceutical process, the proposed method was validated in accordance with International Conference on Harmonization (ICH) guidelines [2-4]. Few analytical methods have been reported in the literature for the estimation of imatinib mesylate and its impurities in bulk drugs and formulations [5-9], but the method for the estimation of imatinib mesylate and its dimer impurity are very scarce in the scientific literature. The aim of current study was to develop a simple, specific, precise, and accurate reverse-phase high-performance liquid chromatography (HPLC) method for the simultaneous determination of imatinib mesylate and its dimer impurity.

\section{METHODS}

Chemicals and reagents

The sample of imatinib mesylate was obtained as gift sample from Nishka Labs and its dimer impurity was procured from Nishka Labs, Hyderabad. All the solvents used were of HPLC grade and all chemicals and reagents were of AR grade. Methanol and acetonitrile of HPLC grade was from Merck Chemicals, Mumbai, while hydrochloric acid and ammonium acetate AR grade were from standard deviation. Fine Chemical Industries, Mumbai. Double-distilled water prepared at laboratory scale using ELGA water purification system and the same was used for the study. Gleevec film-coated tablets were procured from the local pharmacy. It labeled to contain imatinib mesylate equivalent to $100 \mathrm{mg}$ of imatinib free base.

\section{INSTRUMENTATION}

HPLC system (JASCO system) equipped with the model PU 2080 plus pump, rheodyne sample injection port $(20 \mu \mathrm{L})$, MD 2010 photodiode array detector (PDA) detector, and Borwin-PDA software (version 1.5) was used for performing analysis. A chromatographic column HiQ Sil C18 $(250 \mathrm{~mm} \times 4.6 \mathrm{~mm}, 5 \mu \mathrm{m})$ was used for separation. Weighing was done by Shimadzu balance model AY-120.

\section{Chromatographic conditions: Isocratic procedure}

Methanol and acetate buffer $\mathrm{pH} 3.5$ in the ratio of $80: 20 \mathrm{v} / \mathrm{v}$ was the mobile phase used for chromatographic separation which resulted in good resolution and acceptable peak parameters. Flow rate of $1 \mathrm{ml} / \mathrm{min}$ was used for separation and detection with PDA detector at $273 \mathrm{~nm}$. The mobile phase was filtered through a $0.45 \mu$ nylon membrane filter before analysis. The sample injection volume was $20 \mu \mathrm{l}$. 


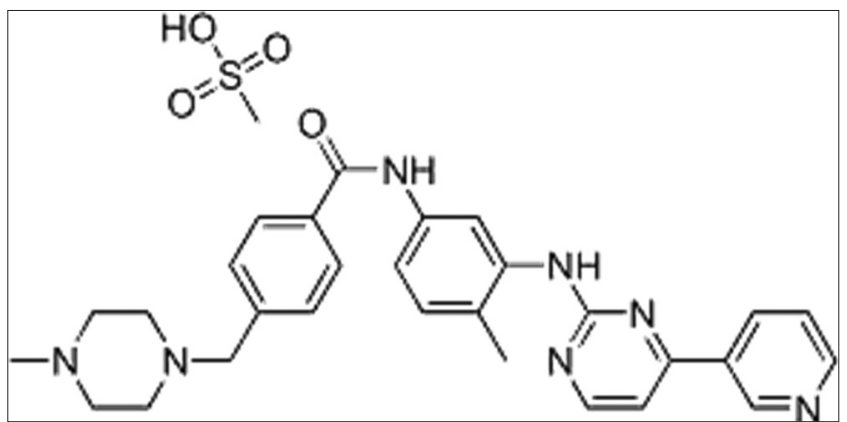

Fig. 1: Chemical structure of imatinib mesylate

\section{Preparation of mobile phase}

Mobile phase was prepared by mixing methanol and acetate buffer pH 3.5 in the ratio of 80:20 v/v. Acetate buffer $\mathrm{pH} 3.5$ was prepared by dissolving $25 \mathrm{~g}$ of ammonium acetate in $25 \mathrm{ml}$ water. $38 \mathrm{ml}$ of $7 \mathrm{M} \mathrm{HCl}$ was added; the $\mathrm{pH}$ was adjusted to 3.5 with $2 \mathrm{M} \mathrm{HCl}$ or $6 \mathrm{M}$ ammonia and diluted with water to $100 \mathrm{ml}$. Then, filter through $0.45 \mu \mathrm{m}$ membrane filter paper using filtration assembly and then sonicated on ultrasonic water bath for 15 min before injecting mobile phase into the HPLC system.

\section{Preparation of solution \\ Standard solution}

Standard stock solution was prepared by dissolving solution "A" (containing $100 \mu \mathrm{g} / \mathrm{ml}$ of dimer impurity was prepared by dissolving $10 \mathrm{mg}$ of dimer impurity in methanol) in a $100 \mathrm{ml}$ volumetric flask. The stock solution "B" was further prepared by diluting suitable amount with methanol to get $10 \mu \mathrm{g} / \mathrm{ml}$ solution of dimer impurity. The imatinib mesylate standard stock solution "C" containing $1000 \mu \mathrm{g} / \mathrm{ml}$ was prepared using required amount of imatinib mesylate reference standard and dissolved in methanol.

\section{Resolution solution}

Solution "D" (resolution solution) was prepared by mixing $1 \mathrm{ml}$ of imatinib mesylate standard stock solution $\mathrm{C}$ and $4 \mathrm{ml}$ of impurity stock solution B, diluted up to $100 \mathrm{ml}$ with methanol. Hence, this solution is containing $10 \mu \mathrm{g} / \mathrm{ml}$ of imatinib mesylate and $0.4 \mu \mathrm{g} / \mathrm{ml}$ of impurity.

\section{Sample solution (for formulation analysis)}

A total of 20 tablets were weighed (each tablet containing imatinib mesylate equivalent to $100 \mathrm{mg}$ of imatinib free base); their mean weight was determined and was finely powdered. The weight of the powder equivalent to $100 \mathrm{mg}$ of imatinib mesylate was transferred into a $100 \mathrm{ml}$ volumetric flask containing $80 \mathrm{ml}$ methanol and sonicated for $5 \mathrm{~min}$ to ensure complete dissolution of drug. Filtration was done, residue was washed with methanol, and volume was made up to the mark by adding washings to the flask. Appropriate volume of above solution was further diluted with methanol to give $20 \mu \mathrm{g} / \mathrm{ml}$ of imatinib mesylate and $20 \mu \mathrm{l}$ was injected into HPLC system, under the specified conditions.

\section{System suitability}

Parameters were evaluated to verify that the analytical system is working properly and can provide accurate and precise results using $20 \mu \mathrm{l}$ resolution solution “ $\mathrm{D}$ ” $(10 \mu \mathrm{g} / \mathrm{ml}$ of imatinib mesylate and $0.4 \mu \mathrm{g} /$ $\mathrm{ml}$ of impurity). Parameters such as peak area, resolution, and tailing factor were calculated. The $\%$ relative standard deviation (RSD) $<2.0$ for six replicate injections and theoretical plates not $<2000$ was set as acceptance criteria.

\section{Analytical method validation}

The method was validated in accordance with ICH guidelines [1-3] and detailed below.

\section{Linearity and range}

The linearity of the method was prepared different linearity solutions in diluent with final concentrations, linearity study of imatinib mesylate was determined over a range of $10-60 \mu \mathrm{g} / \mathrm{ml}$, while for the dimer impurity a range of $0.4-2.4 \mu \mathrm{g} / \mathrm{ml}$. Calibration curve was drawn by plotting the peak areas versus their corresponding concentration in $\mu \mathrm{g} / \mathrm{ml}$. Calculated values of coefficient of regression, slope, and Y-intercept of the calibration curve.

\section{Accuracy (recovery study)}

To perform the accuracy of the proposed method, recovery experiment was carried out by standard addition technique. For this study, tablet powder was first mixed with impurity and appropriately diluted to get sample solution. Recovery studies were performed in triplicate at concentration levels, i.e., $50 \%, 100 \%$, and $150 \%$. Sample solutions were spiked with appropriate volume of standard solution of impurity as well as imatinib mesylate. The resulting mixtures were analyzed by the developed method. Base level amount of imatinib mesylate and its impurity used for spiking was $20 \mu \mathrm{g} / \mathrm{ml}$ and $0.8 \mu \mathrm{g} / \mathrm{ml}$, respectively. Calculation is done for $\% \mathrm{RSD}$ and mean recovery.

\section{Precision}

Repeatability of measurement was determined as intraday variation while intermediate precision was determined by measuring interday variations. Repeatability was measured by injecting 6 times $20 \mu \mathrm{l}$ of standard solution containing imatinib mesylate $(20 \mu \mathrm{g} / \mathrm{ml})$ spiked with impurity solution $(0.8 \mu \mathrm{g} / \mathrm{ml})$ into HPLC system and value of $\%$ RSD was calculated using peak area of imatinib mesylate and impurity. Further, interday variation for the determination of imatinib mesylate and dimer impurity was carried out at three different concentration levels $(20 \mu \mathrm{g} / \mathrm{ml}, 30 \mu \mathrm{g} / \mathrm{ml}$, and $40 \mu \mathrm{g} / \mathrm{ml}$ for imatinib mesylate and $0.8 \mu \mathrm{g} /$ $\mathrm{ml}, 1.2 \mu \mathrm{g} / \mathrm{ml}$, and $1.6 \mu \mathrm{g} / \mathrm{ml}$ for dimer impurity) on 3 consecutive days. The $\%$ RSD of the attained assay values at three different concentration levels was calculated.

\section{Method sensitivity (limit of detection [LOD] and limit of quantification [LOQ])}

The LOD and LOQ were calculated by means of $L O D=3.3 \times \sigma / S$; $\mathrm{LOQ}=10 \times \sigma / \mathrm{S}$, where $\sigma$ is the standard deviation of the $y$-intercepts and $\mathrm{S}$ is the slope of the calibration curve. A series of standard preparation of imatinib mesylate and dimer impurity were prepared over different levels. Calibration graphs were plotted for the obtained area under the curve of each level against the concentration. Slope (S) and standard deviation were calculated to calculate LOD and LOQ.

\section{Specificity}

Specificity is the ability of the method to measure the analyte response in the presence of its potential impurities. It demonstrates the ability of the developed method for the separation and resolution of imatinib mesylate and dimer impurity. Further, peak purity of all the analytes was measured to evaluate the specificity of the method. The sample and standard bands were scanned at for peak start (S), peak apex (M), and peak end (E) positions. PDA detector was used for the determination of peak purity.

\section{Robustness}

To determine the robustness of the developed method, the experimental conditions are altered, such as changing detection wavelength, flow rate, and mobile phase composition was done, and the effects on the area were noted. The $\%$ RSD for each considered change was calculated.

\section{RESULTS AND DISCUSSION}

\section{Development and optimization}

The main objective of the chromatographic method is to separate impurity and main component imatinib mesylate. Chromatographic separation studies were carried from the resolution solution of imatinib mesylate $(10 \mu \mathrm{g} / \mathrm{ml})$ and dimer impurity $(0.4 \mu \mathrm{g} / \mathrm{ml})$. Primarily, chromatographic trials were performed using methanol, 
Table 1: System suitability parameters

\begin{tabular}{|c|c|c|c|c|c|c|}
\hline Name & RT (min) mean $\pm \% R S D$ & Concentration $(\mu \mathrm{g} / \mathrm{ml})$ & Average area & Plates (N) & Tailing factor & Resolution \\
\hline Imatinib mesylate & $8.060 \pm 0.442$ & 10 & 115630.153 & 4156.42 & 1.014 & - \\
\hline Dimer impurity & $11.398 \pm 0.298$ & 0.8 & 2417.783 & 3269.96 & 1.220 & $1.87^{*}$ \\
\hline
\end{tabular}

*With respect to previous peak. RSD: Relative standard deviation

Table 2: Accuracy details of imatinib mesylate and dimer impurity

\begin{tabular}{|c|c|c|c|c|}
\hline \multicolumn{5}{|c|}{ Accuracy results of imatinib mesylate } \\
\hline Accuracy level (\%) & Recovered (mg) & Recovered (\%) & Average (\%) & SD \\
\hline \multirow[t]{3}{*}{50} & 10.077 & 100.771 & 101.57 & 0.75 \\
\hline & 10.225 & 102.247 & & \\
\hline & 10.170 & 101.702 & & \\
\hline \multirow[t]{3}{*}{100} & 20.038 & 100.189 & 99.83 & 0.40 \\
\hline & 19.879 & 99.3959 & & \\
\hline & 19.981 & 99.9038 & & \\
\hline \multirow{3}{*}{150} & 29.939 & 99.7955 & 100.39 & 1.31 \\
\hline & 29.841 & 99.4711 & & \\
\hline & 30.568 & 101.892 & & \\
\hline \multicolumn{5}{|c|}{ Accuracy results of dimer impurity } \\
\hline \multirow[t]{3}{*}{50} & 0.392 & 97.934 & 98.99 & 0.94 \\
\hline & 0.397 & 99.277 & & \\
\hline & 0.399 & 99.746 & & \\
\hline \multirow{3}{*}{100} & 0.804 & 100.464 & 99.18 & 1.16 \\
\hline & 0.791 & 98.879 & & \\
\hline & 0.786 & 98.192 & & \\
\hline \multirow[t]{3}{*}{150} & 1.172 & 97.701 & 98.16 & 0.43 \\
\hline & 1.183 & 98.562 & & \\
\hline & 1.179 & 98.217 & & \\
\hline
\end{tabular}

SD: Standard deviation

Table 3: Details of purity tail and purity front

\begin{tabular}{lll}
\hline Drug/impurity & Purity tail $\mathbf{( s , ~ m )}$ & Purity front (m, e) \\
\hline Imatinib mesylate & 996.26 & 998.48 \\
Dimer impurity & 999.32 & 995.15 \\
\hline
\end{tabular}

water in various proportions along with buffer of different $\mathrm{pH}$, to obtain the required system suitability parameters. After few trials, mixing methanol and acetate buffer $\mathrm{pH} 3.5$ in the ratio of $80: 20 \mathrm{v} / \mathrm{v}$ was chosen as the mobile phase which gave good resolution and acceptable peak parameters. Wavelength for monitoring the eluent was selected by scanning standard solution of drug and impurity within $200-400 \mathrm{~nm}$. At flow rate of $1 \mathrm{ml} / \mathrm{min}$ and detection at $273 \mathrm{~nm}$ separation was carried out. The peak purity was checked with the PDA detector. The mobile phase was filtered through a $0.45 \mu$ nylon membrane filter before use. The injection volume was $20 \mu \mathrm{l}$.

\section{System suitability}

Chromatographic separation of resolution solution D was successfully achieved with the above-mentioned chromatographic conditions. Impurity was injected separately as well as by spiking into the imatinib mesylate to check its interference with the main peak. The impurity peak did not interfere with imatinib mesylate peak. The resolution between imatinib mesylate and dimer impurity was $>1.87$. The retention times of the imatinib mesylate and dimer impurity were 8.060 and 11.398 , respectively. The theoretical plates were above 2000 for both imatinib mesylate and dimer impurity. Table 1 summarizes system suitability parameter details of imatinib mesylate and dimer impurity.

\section{Linearity and range}

The linear calibration plot for the method is obtained over the tested calibration range and the obtained correlation coefficient is $>0.997$. The method was found to be linear over the range (for imatinib mesylate, it was $10-60 \mu \mathrm{g} / \mathrm{ml}$ and for dimer impurity $0.4-2.4 \mu \mathrm{g} / \mathrm{ml}$ ). The revealed results exhibit an excellent correlation between the peak area and analyte concentration. The slope and y-intercept values are given in linearity curves. Linearity curves of imatinib mesylate and dimer impurity are shown in Fig. 2.

\section{Accuracy}

The $\%$ mean recoveries for imatinib mesylate and dimer impurity were in the range of $99.83-101.57$ and $98.16-99.18$, respectively. The overall $\%$ RSD was observed as $<2 \%$. Accuracy details are given in Table 2 .

\section{Precision and Repeatability}

In precision studies, the $\%$ RSD was found to be 0.50 for repeatability and $0.13-1.63 \%$ interday for imatinib mesylate. In precision studies, the \% RSD was found to be 0.97 for repeatability and $0.28-0.95 \%$ interday for dimer impurity, indicating that the method is precise.

\section{Method sensitivity}

The LOD concentration was found to be $0.570 \mu \mathrm{g} / \mathrm{ml}$ for imatinib mesylate and $0.033 \mu \mathrm{g} / \mathrm{ml}$ dimer impurity, and LOQ concentration was $1.728 \mu \mathrm{g} / \mathrm{ml}$ for imatinib mesylate and $0.099 \mu \mathrm{g} / \mathrm{ml}$ dimer impurity.

\section{Specificity}

The specificity of the method was established by peak purity profiling studies. The peak purity values were found to be more than 995 , indicating the no interference of any other peak of degradation product, impurity, or matrix. Details about purity tail and purity front of imatinib mesylate and dimer impurity are given in Table 3.

\section{Robustness}

When small but deliberate changes were made to chromatographic conditions, no significant effect was observed on system suitability parameters. $\%$ RSD was $<2 \%$ indicating that the developed method was robust to changes in the experimental conditions. Data of robustness details are given in Table 4. 




Fig. 2: Linearity curve of imatinib mesylate and dimer impurity

Table 4: Robustness details of imatinib mesylate and dimer impurity

\begin{tabular}{|c|c|c|c|c|}
\hline Parameters & Measure & Average & SD & \% RSD \\
\hline \multicolumn{5}{|l|}{ Robustness for imatinib mesylate } \\
\hline \multirow[t]{3}{*}{ Change in wavelength } & $273 \mathrm{~nm}$ & 101.8734 & 0.1938 & 0.1902 \\
\hline & $272 \mathrm{~nm}$ & 100.5271 & 0.1094 & 0.1089 \\
\hline & $274 \mathrm{~nm}$ & 102.5178 & 0.1670 & 0.1629 \\
\hline \multirow[t]{3}{*}{ Change in flow rate } & $1 \mathrm{ml} / \mathrm{min}$ & 101.6747 & 1.0700 & 1.0524 \\
\hline & $0.95 \mathrm{ml} / \mathrm{min}$ & 101.3891 & 1.6923 & 1.6691 \\
\hline & $1.05 \mathrm{ml} / \mathrm{min}$ & 100.1811 & 0.8046 & 0.8032 \\
\hline \multirow{2}{*}{ Change in mobile phase composition* } & $82: 18$ & 100.7539 & 0.6061 & 0.6016 \\
\hline & $78: 22$ & 101.1562 & 0.1123 & 0.1110 \\
\hline \multicolumn{5}{|l|}{ Robustness for dimer impurity } \\
\hline \multirow[t]{3}{*}{ Change in wavelength } & $273 \mathrm{~nm}$ & 101.086 & 0.502 & 0.496 \\
\hline & $272 \mathrm{~nm}$ & 100.964 & 0.620 & 0.614 \\
\hline & $274 \mathrm{~nm}$ & 100.361 & 0.349 & 0.348 \\
\hline \multirow[t]{2}{*}{ Change in flow rate } & $1 \mathrm{ml} / \mathrm{min}$ & 101.517 & 0.995 & 0.980 \\
\hline & $0.95 \mathrm{ml} / \mathrm{min}$ & 100.333 & 0.892 & 0.889 \\
\hline \multirow[t]{3}{*}{ Change in mobile phase composition* } & $80: 20$ & 100.228 & 0.845 & 0.843 \\
\hline & $82: 18$ & 99.671 & 1.029 & 1.033 \\
\hline & $78: 22$ & 100.191 & 0.521 & 0.520 \\
\hline
\end{tabular}

*Methanol: Buffer. SD: Standard deviation, RSD: Relative standard deviation

\section{CONCLUSION}

The method validation results have been proved that the method to be linear, precise, accurate, specific, and robust. The developed method was validated in accordance with ICH guidelines.

The method was found to be linear in stated range. Statistical evaluation proved that the method is specific, accurate, precise, and sensitive. The method is suitable for simultaneous quantitative analysis of imatinib mesylate and its dimer impurity in bulk drugs and formulations without any interference from the excipients. Thus, the proposed method can be successfully employed for routine quality control and impurity profiling of imatinib mesylate.

\section{ACKNOWLEDGMENT}

The authors are thankful to Dr. Jagadeesh Kumar Kuna, RMC Kakinada, for his encouragement and we greatly thank Nishka Labs, Hyderabad, for providing all the necessary facilities to carry out this work.

\section{AUTHORS CONTRIBUTION}

All the authors have contributed equally.

\section{CONFLICT OF INTEREST}

Conflict of interest declared none.

\section{REFERENCES}

1. Sweetman SC. Martindale: The Complete Drug Reference. $36^{\text {th }}$ edition. London: Pharmaceutical Press; 2009. p. 773-4.

2. International Conference on Harmonization of Technical Requirements for Registration of Pharmaceuticals for Human Use. Validation of Analytical Procedures: Definition and Terminology ICH Q2A; 1995.

3. International Conference on Harmonization of Technical Requirements for Registration of Pharmaceuticals for Human Use. Validation of Analytical Procedures: Methodology ICH Q2B; 1997.

4. International Conference on Harmonization of Technical Requirements for Registration of Pharmaceuticals for Human Use. Validation of analytical procedures: Text and Methodology ICH Q2 (R1); 2005.

5. Yadav RR, Rokade MD, Salunke SA, Gangrade DM, Holkar GS, Daphal VN. Determination of potential genotoxic impurities in imatinib mesylate by RP-HPLC method. Biol Forum Int J 2012;4:15-8.

6. Madireddy V, Kondra SB, Narayanareddy P. Stability-indicative, validated, fast HPLC method for quantification of two genotoxic impurities in imatinib mesylate. Glob J Anal Chem 2011;2:198-207.

7. Ghrib F, Chtioui A, Saied T, Bellakhal N. Determination of imatinib and its genotoxic impurities in tablets. Biol Forum Int J 2015;7:1820-7.

8. Shah P, Shah R. A stability-indicating RP-HPLC method development and validation for the related substance determination of imatinib process impurities and their degradation products in tablet dosage form. Int J PharmTech Res 2015;8:128-46.

9. Smita JP, Rajendra CD, Priya PD. Development of UVSpectrophotometric method for the determination of imatinib mesylate (ITM) in bulk and formulation. Asian J Pharm Clin Res 2013;6:54-7. 